\section{THE SUPPLY OF VACCINE LYMPH.}

\section{To the Editors of THE LANCET.}

SIRs,-The following letter has been sent from the governing body of the Jenner Institute of Preventive Medicine, over which Lord Lister presides, to a correspondent who had written concerning the confusion existing in the public mind from the fact that there are two Jenner Institutes, in one of which-that at Chelsea-the Government lymph supplied gratis to public vaccinators is prepared, while in the other-that at Battersea-vaccination lymph is prepared and sold commercially. The Government lymph, as is generally known, cannot be purchased.

Feb. 12th, 1902 . I am, Sirs, yours faithfully,

Jenner Institute of Preventive Medicine, Grosvenor-road, Chelsea Gardens, S.W., Feb. 11th, 1902.

SIR,- In reply to your letter I am directed to inform you that no vaccine Iymph is prepared at the Jenner Institute of Preventive Medicine under the direction of the governing body of the institute, but that certain laboratories in the institute are leased to the Local that certain laboratories in the institute are leased to the Local in preparing glycerinated lymph for supplying public vaceinators only. The manufacture of calf lymph for sale is also carried on at another institute, the Jenner Institute for Calf Lymph, situated in Battersea but that institute is in no way connected with the Jenuer Institute of Preventive Medicine. I am, \&c.,

AllaN MACFADYEN (Secretary).

\section{THE LAY PRESS ON THE TREATNENT OF CONSUMPTION.}

To the Editors of THE LANCET.

SrRs,-There have recently appeared in a journal of the daily press certain articles relating to a treatment of pulmonary tuberculosis by intravenous injection, and stated to be a "cure for consumption," discovered by me. I have discovered no such cure. The suggestion of treatment by such means I put before the profession more than a year ago. It is on its trial and as yet its results do not warrant any authoritative opinion, still less such positive assertions as have been published. I greatly deprecate that, by no fault of mine, the matter should have obtained access to the lay press.

I am. Sirs, yours faithfully,

Seymour-street, W., Feb. 5th, $1902 . \quad$ RobERT MAGUIRE.

\section{CANCER AMONG HINDOOS.}

To the Editors of THE LANCET.

SIRS, - As Captain Donovan cannot, or will not, furnish the information as regards the custom of circumcision among the Mahomedans, which Mr. Keetley asked for in THE LANCET of Jan. 18th, I beg to state that the rite is canonically enjoined upon all the followers of Mahomet; all converts also have to be circumcised and as a matter of practice circumcision is more universal among the Indian Mahomedans than is baptism in Christian England. So universal is the custom that in some parts of India the Mahomedans owe their sobriquet "Katro" " the cut" or " circumcised") to this practice. In fact, in a vulgar brawl a Hindoo will taunt at the Mahomedan as the "cut" one. As your readers will know, the term Mahomedan is not a racial but a denominational designation. The Indian Mahomedans call themselves Mussulmans. The Hindoos either accord them this title or call them variously as "Turiks" (Turks), Naithe (from Inam-corruption, I believe), Moplah, Lubbe, \&c., but outside of officialdom the word Mahomedan is seldom heard in the mouth of a native of India.

I may say here that I have seen Captain Donovan's reference to me in THE LANCET of Jan. 4th and I cannot help observing that the time and space spent by him in his attempts at my biography would have been better devoted to a recollection of his cancer cases, so that we might have had a rough total, though, as it would seem, his "case-books" were out of reach just then; but I have no doubt that when he has once returned to his station and is settled down he will have time to look up his case-books and we will then have some definite idea of the number of cancer cases which he has operated upon or otherwise treated during his three years' active surgical work on the Malabar coast. The two provinces he speaks of have a population as large as that of Ireland. The people have little communication with the outside world. There are no railways (at least, there were none when I was there $(20$ years ago), only a weekly steamer communication between the principal ports, and that only when the monsoons permitted. Besides, though these two provinces form part of the Madras Presidency the natives are by language, race, and manners strangers in the other 30 and odd districts of the Madras Presidency and to the city of Madras itself, where the "General Hospital" is located and to which Captain Donovan tells us all the afflicted from the $40,000,000$ go up for operation.

For the reasons I have mentioned these two provinces could not have furnished the Madras General Hospital many patients, as it is at best a four or five days' tedious journey thereto. Besides, Malabar women are absolutely forbidden (I mean the "Nair" women, the caste women) to go beyond the limits of Malabar. Under these circumstances the Madras General Hospital could not have drawn much upon Captain Donovan's own resources, and he must have found his hands quite full during the three years of his active surgical work, especially as few other operating surgeons, I believe, have ever penetrated to Malabar and Canara.

I need not comment here upon Colonel Maitland's letters (as the evidence furnished therein, as Mr. Keetley has shown in his letter in THE LANCET of Jan. 18th, is inconsistent and self-contradictory) further than to say that I am glad to learn therefrom that female patients are now admitted to the Madras General Hospital. It is the only clinical hospital for 40,000,000, and when I looked through the wards in 1889 or 1890 (I am not sure exactly which year) there were no female patients there, and I was told that females are not admitted there- "not one in 10 years, and that the hospital is intended solely for men." Under the new regulation, is it only cancer cases that are so favoured, or are all females? I am, Sirs, yours faithfully,

Percy-road, Ravenscourt-park, W., Jan. 29th, 1902

\section{N. SALDANHA.}

PS. - As regards the word Hindoo, it is used in two ways. 1. The more strict and in the sense always used by the natives themselves it comprises the four classes of Brahmins, Shaitrayas, Vaisayas, and Sudras. In other words, it is synonymous with "Casteman." It would be seen from this that the outcasts, variously called "Mars" and "Pariahs," do not come under this category. 2. It is used in a denominational sense. All non-Mahomedan natives are Hindoos. In this sense these outcasts become Hindoos too (but they may not knock at the door of a Hindoo of the first category), as they also worship the Brahmin gods. The religion is called Brahminism or Hindooism and all the followers therefore become Brahminists and Hindoos. This leads to confusion and is responsible for much of the ridiculous statements one sees made by foreigners. For instance, in THE LANCET of Jan. 18th, p. 192, Mr. W. Roger Williams, referring to the North West Provinces, says: "Four-fifths of the inhabitants are Hindoos who, in accordance with the precepts of their religion, never eat meat." Mr. Williams must have read somewhere that Brahmins do not eat meat. Brahmins are Hindoos, therefore all Hindoos may not eat meat. As a matter of fact, Brahmins comprise a very small fraction of the total number of Hindoos. In fact, they are only the priestly class and are in a great minority. All other Hindoos-Rajapoots (the princely class), Vaisayas (the merchants), and Sudras (the cultivators)-do eat meat, but they may not eat beef. Pariahs, of course, are allowed to eat anything, and from Pariahs come domestics, barbers, washermen, \&c., of Europeans, for a caste man may neither shave, eat with, cook. nor wash for a European. This rule is very rigidly observed, especially in Madras, where Colonel Maitland and Captain Donovan are serving. Still, I am afraid that Colonel Maitland uses the word Hindoo in the sense No. 2. I used it in the meaning of No. 1.

\section{DYSENTERY IN ASYLUMS.}

\section{To the Editors of THE LANCET.}

SiRs,-May I be permitted to make a correction in the report in THE LANCET of Feb. 1st, p. 307, of the remarks which I made on Dysentery in Asylums at the meeting of the Epidemiological Society on Jan. 17th? The outbreak at the Leavesden Asylum was not unreported. An account of it will be found in the Medical Supplement to the Annual Report of the Statistical Committee of the Metropolitan Asylums Board for 1899 . Though there were several fatal cases, yet in not one was ulceration of the colon found, such 